Israel Law Review 54(3) 2021, pp 305-323. C The Author(s), 2021. Published by Cambridge University Press in association with the Faculty of Law, the Hebrew University of Jerusalem. This is an Open Access article, distributed under the terms of the Creative Commons Attribution licence (http:// creativecommons.org/licenses/by/4.0/), which permits unrestricted re-use, distribution, and reproduction in any medium, provided the original work is properly cited.

doi:10.1017/S0021223721000157

\title{
Israeli Pre-Transitional Justice and the Nakba LaW
}

\author{
Yoav Kapshuk (D) and Lisa Strömbom*
}

First published online on 13 September 2021

\begin{abstract}
Pre-transitional justice activities that expose past injustices during entrenched conflicts can incite strong reactions among actors who feel threatened by or dislike such activities, and who thus attempt to silence controversial truths. This article illuminates how attempts to silence controversial truths, in parallel with shutting down debate, can also have the unintended outcome of enlarging public discourse on previously marginalised issues. Thus, paradoxically, efforts to curb freedom of expression sometimes result instead in an expanded public capacity to debate previously silenced truths about the conflict. We conduct a case study of reactions to pre-transitional justice in Israeli society focusing on the so-called Nakba Law, enacted in 2011. Through interviews with members of the non-governmental organisation Zochrot, politicians, teachers and media persons, we first show the relationship between pre-transitional justice and enacting the Nakba Law. We then demonstrate that while the Nakba Law indeed aimed to hamper freedom of expression, it also enabled increased public knowledge about the meaning of Nakba. Our theoretical proposition regarding this paradox, in this case activated by instigating new memory laws, is highly relevant to other conflicts-in-resolution that experience pre-transitional justice processes.
\end{abstract}

Keywords: transitional justice (TJ), pre-transitional justice, truth, ontological security, Israeli-Palestinian conflict, Nakba, Nakba Law

\section{INTRODUCTION}

This study explores pre-transitional justice (pre-TJ) actions and subsequent state reactions. In particular, we examine whether the Israeli so-called Nakba Law ${ }^{1}$ can be understood as a reaction to the pre-TJ actions of the non-governmental organisation (NGO) Zochrot, which works to expose Nakba narratives to the Jewish-Israeli public. ${ }^{2}$ To this end, the study analyses the impact of the Nakba Law on Israeli public discourse about the Nakba. In the first section we detail the theoretical starting points for the study centred on the concepts of pre-TJ and ontological security. In the second section we turn our attention to the NGO Zochrot and its pre-TJ activities, as well as to the Nakba Law as a counterreaction by the Israeli state. The following sections show that while the Nakba Law is part of a range of other laws that curtail freedom of expression by defining which topics are legitimate to speak about and

\footnotetext{
${ }^{\dagger}$ The online version of this article has been updated since original publication. A notice detailing the changes has also been published.

"Yoav Kapshuk, Lecturer, Kinneret College on the Sea of Galilee, Israel; kapshuk@gmail.com. Lisa Strömbom, Associate Professor, Lund University, Sweden; Lisa.strombom@svet.lu.se.

The authors thank the reviewers and the senior and student editors of the Israel Law Review for their valuable comments. Any errors or oversights that remain are solely the responsibility of the authors.

The article was written partly within the project 'Pushing the Boundaries of Peace Research: Reconceptualizing and Measuring Agonistic Peace' (PUSHPEACE), funded by Riksbankens Jubileumsfond through a Swedish Foundations Starting Grant (grant number RIK18.1441.1).

${ }^{1}$ The Nakba ('the Catastrophe') is the term for the Palestinian exodus during the 1947-48 war, when more than 700,000 Palestinians fled or were expelled from their homes.

${ }^{2}$ Zochrot, 'Our Vision', 11 March 2020, https://zochrot.org/en/content/17.
} 
which are not, it has, ironically, contributed to increased recognition of the word 'Nakba' and its meaning in mainstream Israeli discourse. The study contributes to the literature of TJ by showing how pre-TJ actions in ongoing conflicts-in-resolution can invoke discursive dynamics that reach the public through debate in the media and the political and judicial sphere. An outcome of this is that previous taboo topics, such as normative dimensions regarding the conflict's alleged victims and perpetrators, can then be vented and reach public awareness, even though the general climate might be more closed and restrictive to new narratives than ever.

Qualitative data comes from semi-structured and follow-up interviews ${ }^{3}$ with 25 respondents ${ }^{4}$ and participant observation at nine public Zochrot events such as "We Thought It Is Temporary": Taking Responsibility on Israel's Independence Day'. ${ }^{5}$ At such events, the authors coordinated interviews with Zochrot members, ${ }^{6}$ which were subsequently conducted face-to-face via Zoom software or by phone. ${ }^{7}$ To present a broad picture of the impact of the Nakba Law, we conducted interviews with Zochrot activists, a diverse set of politicians, teachers and media persons with relevant knowledge of the unfolding of events pertaining to the Nakba Law. To further corroborate our knowledge of the context in which the law was debated and enacted, we drew from primary source texts such as policy reports, Zochrot publications and newspaper articles.

\section{Pre-transitional Justice and Its Responses}

'Transitional justice' is a general term for activities that aim to achieve common understandings and/or agreement between parties that are in transition from a state of violent conflict to peace. The concept of TJ is often defined as 'the full range of processes and mechanisms associated with a society's attempts to come to terms with a legacy of large-scale past abuses, in order to ensure accountability, serve justice and achieve reconciliation'. ${ }^{8} \mathrm{TJ}$ literature and practice focused initially on the legal responses of postcolonial regimes to injustices perpetrated by previous oppressive regimes. ${ }^{9}$ As the research field developed, the concept of TJ expanded beyond the legal area

\footnotetext{
${ }^{3}$ Nigel King, Christine Horrocks and Joanna Brooks, Interviews in Qualitative Research (2nd edn, SAGE 2018).

${ }^{4}$ Robert S Weiss, Learning from Strangers: The Art and Method of Qualitative Interview Studies (Simon and Schuster 1995).

${ }^{5}$ Zochrot, “'We Thought It Is Temporary”: Taking Responsibility on Israel's Independence Day', 14 April 2021, https://zochrot.org/en/event/56431.

${ }^{6}$ The authors are not members of the NGO Zochrot.

${ }^{7}$ We used the snowball method of recruitment. Although the snowball method is typically used when studying hidden research populations, it is also used as a complementary method when the researcher no longer has a broad connection with the field. In the current study, the authors knew some Zochrot activists from earlier research and during those interviews asked for the names of other activists, who were subsequently contacted and interviewed (Nissim Cohen and Tamar Arieli, 'Field Research in Conflict Environments: Methodological Challenges and Snowball Sampling' (2011) 48 Journal of Peace Research 423, 424-27; Chaim Noy, 'Sampling Knowledge: The Hermeneutics of Snowball Sampling in Qualitative Research' (2008) 11(4) International Journal of Social Research Methodology 327, 330-31.

${ }^{8}$ UN Secretary General, Guidance Note of the Secretary-General: United Nations Approach to Transitional Justice (March 2010), UN Doc ST/SG(09)/A652, 2.

${ }^{9}$ Ruti Teitel, 'The Law and Politics of Contemporary Transitional Justice' (2005) 38 Cornell International Law Journal 837, 838, 840-41.
} 
to include a variety of ways of dealing with past injustices while integrating issues such as history, truth, memory and identity. ${ }^{10} \mathrm{TJ}$ is also used within the political sphere of policy and practice, such as in establishing and documenting the activities of institutions such as international courts, truth and reconciliation commissions, reparation programmes, human rights organisations and victim organisations in peace-building activities. ${ }^{11}$ Prominent contributions to the field of conflict resolution view TJ as a post-conflict instrument whereby a society addresses situations of transition from dictatorship to democracy or from conflict to reconciliation. ${ }^{12}$

In reality, however, TJ activities are conducted while conflict is ongoing and sometimes simultaneously with peace negotiations (as in the case of the Colombian government negotiations with the Revolutionary Armed Forces of Colombia (FARC)), ${ }^{13}$ or sometimes before the initiation of a peace process or even after a peace process has failed (as in Israel after 2001 when bilateral peace negotiations with the PLO broke down). ${ }^{14}$ Such TJ processes that occur while conflict is ongoing are often conceived of as 'pre-TJ' or 'critical TJ', thus challenging the mainstream TJ discourse which tends to focus on top-down universal formulas and state institutions. ${ }^{15}$ The main difference between $\mathrm{TJ}$ and pre-TJ is that the former is carried out by state institutions, while the latter is undertaken by civil society organisations. ${ }^{16}$ For example, the Truth and Reconciliation Commission in South Africa was established by the state, but in the ongoing Israel-Palestine conflict and in the absence of similar initiatives performed by the state, a truth committee was established by the NGO Zochrot. ${ }^{17}$

Although pre-TJ activities are generally carried out by civil society organisations, there are some important differences between various kinds of pre-TJ activity:

1. Pre-TJ activities following the end of a conflict after which the state has transitioned to democracy: compared with TJ actions performed by the state after a conflict has ended, pre-TJ is a bottom-up, civil society action which attempts to change public opinion and

\footnotetext{
10 'Editorial Note' (2007) 1 International Journal of Transitional Justice 1, 2.

${ }^{11}$ Kieran McEvoy and Louise Mallinder, Transitional Justice, Vol III (Routledge 2016).

${ }^{12}$ Yaacov Bar-Siman-Tov, 'Linking Peace and Justice in Peacemaking' in Karin Aggestam and Annika Bjorkdahl (eds), Rethinking Peacebuilding: The Quest for Just Peace in the Middle East and the Western Balkans (Routledge 2013) 19.

${ }^{13}$ Yoav Kapshuk, 'Transitional Justice in the Israeli-Palestinian Negotiations: What Can Be Learned from the Colombian Case?' (2019) 14 Journal of Peacebuilding \& Development 73, 74.

${ }^{14}$ Ron Kedar and Ron Dudai, 'Imagined Law: Civil Society, Literature and Justice, Critical Transitions in Israel' (2018) 50 Theory and Criticism 371, 374 (in Hebrew).

${ }^{15}$ Jessica Nevo, 'Transitional Justice Models and their Applicability to the Zionist-Palestinian Conflict' in Terry Rempel (ed), Rights in Principle - Rights in Practice: Revisiting the Role of International Law in Crafting Durable Solutions for Palestinian Refugees (Badil 2009) 327, 332-33; Dustin N Sharp, 'What Would Satisfy Us? Taking Stock of Critical Approaches to Transitional Justice' (2019) 13 International Journal of Transitional Justice 570, 576-80; Kedar and Dudai (n 14) 376-78.

${ }^{16}$ Kedar and Dudai (n 14) 376-78.

${ }^{17}$ Zochrot, 'Truth Commission for the Nakba in the Negev 1948-1960', 31 December 2015, https://zochrot.org/ en/keyword/45328; Nevo (n 15) 336-37.
} 
urge the establishment to change its current policies. ${ }^{18}$ For example, during the $1990 \mathrm{~s}$ in Argentina, a group of young people demonstrated in front of the homes of individuals who had committed human rights violations during the military dictatorship (1976-83) and lived anonymously without ever paying the price for the injustice they committed. ${ }^{19}$ The demonstrators acted to expose to the public the past actions of those individuals and bring about alternative justice and truth, as legal justice from the establishment had been denied. Such actions are often guided by the assumption that serious and sustained demands for justice stemming from below can push authorities to prosecute the alleged criminals even though they have refrained from doing so previously. ${ }^{20}$

2. Pre-TJ actions taking place in countries where no significant changes have been made and where authoritarian rule is still in place: ${ }^{21}$ pre-TJ in such cases is intended to incentivise democratic rule, as in the case of Myanmar. ${ }^{22}$

3. Pre-TJ activities carried out by civil society actors during entrenched conflicts: ${ }^{23}$ a key element of pre-TJ during conflicts is to use and 'copy' procedures from the legal arena and from official institutions, and use those in the informal sphere of civil society activities to demand that authorities claim responsibility for past wrongs. ${ }^{24}$ This may be achieved by civil society organisations imagining and suggesting institutional and noninstitutionalised TJ procedures for the future. ${ }^{25}$ Activities such as unofficial truth commissions can also be useful tools for $\mathrm{TJ}$ as they are amenable to alternative perspectives. $^{26}$ These types of bottom-up perspective have challenged top-down legalist paradigms, which determine what is emphasised and what is marginalised. ${ }^{27}$

Pre-TJ in Israel takes place in the context of an ongoing entrenched conflict. During the greater part of the 1990s negotiations between Israel and the Palestinians focused on trying to resolve the outcome of the 1967 war and not on the roots of the conflict; this left difficult questions at the core of the conflict for the future, such as the question of return of Palestinian refugees from $1948 .{ }^{28}$ However, since

\footnotetext{
${ }^{18}$ Similar to the description of Kedar and Dudai (n 14), that the activity of TJ is carried out instead, and also to encourage TJ activity by the state during an active conflict, here it is also undertaken in situations where the conflict has ended and society has become democratic.

${ }^{19}$ Noa Vaisman, 'Variations on Justice: Argentina's Pre- and Post-Transitional Justice and the Justice to Come' (2017) 82 Ethnos 366, 370-73.

20 ibid 374.

${ }^{21}$ Roman David and Ian Holliday, 'Set the Junta Free: Pre-Transitional Justice in Myanmar's Democratisation' (2006) 41 Australian Journal of Political Science 91, 93-94, 101.

22 ibid 94.

${ }^{23}$ Ron Dudai and Hillel Cohen, 'Dealing with the Past when the Conflict Is Still Present: Civil Society Truth-Seeking Initiatives in the Israeli-Palestinian Conflict' in Rosalind Shaw, Lars Waldorf and Pierre Hazan (eds), Localizing Transitional Justice: Interventions and Priorities after Mass Violence (Stanford University Press 2010) 228, 236.

${ }^{24}$ Kedar and Dudai (n 14) 376-77.

25 ibid.

${ }^{26}$ Marcos Zunino, 'Subversive Justice: The Russell Vietnam War Crimes Tribunal and Transitional Justice' (2016)

10 International Journal of Transitional Justice 211, 216-19.

27 ibid 227-28.

${ }^{28}$ Yehuda Shenhav, In the Trap of the Green Line (Am Oved 2010) 23 (in Hebrew).
} 
the failure of the peace process in 2000 there has been a growing understanding in Israel that without addressing the deep-rooted causes of the conflict and, at the very least, acknowledging the effect of the 1948 war on Palestinians, it may not be possible to bring an end to the conflict. ${ }^{29}$ Since the collapse of the peace process, and faced with socio-political unwillingness to engage in a discourse about accepting responsibility, Israeli civil society has developed its own versions of TJ as a means to provoke crucial discussions about how to deal with past injustices. Activists borrowed from state-led TJ strategies in the legal arena and transferred them to the sphere of civil society. ${ }^{30}$ For example, the 'Land for All' initiative embodies a new vision for Palestinian-Israeli peace by stating that 'the resolution to the conflict cannot ignore or evade the "1948 question". ${ }^{31}$ Moreover, other civil society organisations have started to adopt pre-TJ activities, such as the Israeli-Palestinian Joint Memorial Day Ceremony, hosted jointly by Israeli Palestinian Bereaved Families for Peace and Combatants for Peace, which has been held every year since $2007 .{ }^{32}$ Mutual recognition of past and current suffering of both parties, as is reflected in such events, is essential for promoting reconciliation. ${ }^{33}$

This article contributes to the above scholarship on pre-TJ 'from below' during entrenched conflicts. ${ }^{34}$ We apply the concept of pre-TJ to a case study of the Nakba Law and how it has been elaborated by authorities and civil society in Israel. We show how pre-TJ activities can promote transitions from a culture of denial and impunity to one of recognition and accountability. To further advance knowledge of the pre-TJ concept, we elaborate on reactions to pre-TJ activities and their societal consequences.

\subsection{Paradoxical Responses}

$\mathrm{TJ}$ activities that expose silenced injustices from the past, especially in post-conflict societies, may (in theory) contribute to constructive transformation between parties, thus improving relations as new opportunities for transformation emerge. ${ }^{35}$ However, societies that are engaged in deep-rooted conflict tend to form group identities around hostility towards and fear of the other side. ${ }^{36}$ In such cases, pre-TJ activities with the aim of dealing with past injustices are often perceived as a threat to central collective narratives and identities. ${ }^{37}$ When such disruptions

\footnotetext{
${ }^{29}$ Kedar and Dudai (n 14) 374.

30 ibid 377-78.

${ }^{31}$ An Open Land for All, 'A New Vision for Palestinian-Israeli Peace: Draft for Discussion,' 2021, 5, https://www. alandforall.org/wp-content/uploads/2021/02/booklet-english.pdf.

32 The Israeli-Palestinian Memorial Day Ceremony, 13 April 2021, https://www.theparentscircle.org/en/pcff-activities_eng/memorial-ceremony_eng/\#2021.

${ }^{33}$ Dudai and Cohen (n 23) 235-36.

${ }^{34}$ Kieran McEvoy and Lorna McGregor, 'Transitional Justice from Below: An Agenda for Research, Policy and Praxis' in Kieran McEvoy and Lorna McGregor (eds), Transitional Justice from Below: Grassroots Activism and the Struggle for Change (Bloomsbury 2008) 1, 2-6.

${ }^{35}$ Lisa Strömbom, 'Thick Recognition: Advancing Theory on Identity Change in Intractable Conflicts' (2014) 20 European Journal of International Relations 168, 186, 172.

${ }^{36}$ Daniel Bar-Tal and others, 'Ethos of Conflict: The Concept and its Measurement' (2012) 18 Peace and Conflict: Journal of Peace Psychology 40, 42-43.

${ }^{37}$ Dudai and Cohen (n 23) 247.
} 
occur, people can either abandon or transform their previous identities, while others more rigidly adhere to and defend them, and sometimes even fight for them. ${ }^{38}$

The concept of ontological security, ${ }^{39}$ originally adopted by Giddens,${ }^{40}$ highlights the psychological mechanisms through which individuals and collectives uphold a sense of security and meaning to experience a continuous self-identity. ${ }^{41}$ Ontological insecurity, by contrast, describes discontinuity in one's sense of self, which instead gives rise to anxiety and existential fear. ${ }^{42}$ When core identity narratives are disrupted, people can feel a profound sense of insecurity, ${ }^{43}$ and heightened levels of ontological insecurity can trigger processes whereby objects of fear must be re-established. ${ }^{44}$ Thus, when presented with alternative views about the past which disrupt core identity narratives, some individuals and groups will react forcefully to silence those views; this re-establishes the firm boundary between the self and some feared or hated other. ${ }^{45}$ It might be visible in different accounts where the other is forcefully delegitimised alongside simultaneous delegitimising efforts of those belonging to the in-group who publicly disseminate narratives of recognition of the other. ${ }^{46}$

Lupovici utilised an elaborate framework of ontological security to explore the psychological dynamics involved in trying to understand conflicts-in-resolution, in general, and the Israeli-Palestinian conflict, in particular. ${ }^{47}$ Our empirical focus is conducted by linking ideas of ontological security to pre-TJ, and by connecting pre-TJ activities with the concept of le différend (the difference). Lyotard's '[t]he différend is the unstable state and instate of language wherein something which must be able to be put into phrase cannot yet be ... [t] his state is signalled by what one ordinarily calls a feeling: "One cannot find the words". ${ }^{48}$ In Israeli-Palestinian relations, before pre-TJ activities and the counter-effects of the Nakba Law, the state of différend was that there was no way to express what happened in 1948 in terms other than phrases of war. ${ }^{49}$ The phrase 'Nakba' and the Palestinian narrative did not exist in the Hebrew language or in Jewish Israeli discourse. Pre-TJ activities, such as those of

\footnotetext{
${ }^{38}$ Patricia Greve, 'Ontological Security, the Struggle for Recognition, and the Maintenance of Security Communities' (2018) 21 Journal of International Relations and Development 858, 864.

${ }^{39}$ Catarina Kinnvall and Ted Svensson, 'Ontological Security and the Limits to a Common World: Subaltern Pasts and the Inner-Worldliness of the Tablighi Jama'at' (2017) 20 Postcolonial Studies 333, 336.

${ }^{40}$ Anthony Giddens, Modernity and Self-Identity: Self and Society in the Late Modern Age (Stanford University Press 1991) 35-42.

${ }^{41}$ ibid 35.

42 Jelena Subotic, 'Political Memory, Ontological Security, and Holocaust Remembrance in Post-Communist Europe' (2018) 27 European Security 296, 298.

${ }^{43}$ Bahar Rumelili and Ayşe Betül Çelik, 'Ontological Insecurity in Asymmetric Conflicts: Reflections on Agonistic Peace in Turkey’s Kurdish Issue’ (2017) 48 Security Dialogue 279, 281-82.

44 ibid.

${ }^{45}$ ibid.

${ }^{46}$ Christopher S Browning and Pertti Joenniemi, 'Ontological Security, Self-Articulation and the Securitization of Identity' (2017) 52 Cooperation and Conflict 31, 45.

${ }^{47}$ Amir Lupovici, 'Ontological Dissonance, Clashing Identities, and Israel's Unilateral Steps towards the Palestinians' (2012) 38 Review of International Studies 809, 819-33.

48 Jean-François Lyotard, Le Différend (6th edn, University of Minnesota Press 2002 [1988]) 13.

${ }^{49}$ We thank Dr Tom Pessah for the idea of linking the theoretical aspect of 'le différend' to the case of the phrase 'Nakba' in the Israeli public.
} 
Zochrot, functioned to educate the broader Israeli public about the taboo topic of Nakba. In response to such activities, the Israeli state enacted the Nakba Law to silence public discourse and reaffirm its taboo status. This study highlights the discursive dynamics whereby pre-TJ activities that raised awareness about Nakba led to a law intended to silence Nakba narratives which, ironically, had the opposite effect and instead increased public discourse and knowledge regarding the Nakba. By this case study we discuss the long-term consequences of alternative narratives being brought back into consciousness by renewed debate and how it is relevant to other conflicts-in-resolution.

This study zooms in on two possible discursive dynamics spurred by pre-TJ activities. The first, driven by ontological insecurity, attempts to silence alternative narratives that threaten core identities. The second, driven in part by such attempts at silencing, instead further opens public discussion and debate on those previously unspoken alternative narratives.

In the first dynamic the implications of pre-TJ activities might ignite a process whereby freedom of speech is inhibited, thus weakening liberal democratic discourse. In this process the state uses the legal system to block counter-hegemonic interpretations as a means of maintaining a positive perception of its violent past. ${ }^{50}$ Responses to TJ actions that raise awareness of past injustices include efforts to mis-recognise ${ }^{51}$ (contrary to an act of recognition) and silence those who promote $\mathrm{TJ}$ actions. ${ }^{52} \mathrm{We}$ suggest that this may be a result of feelings of ontological insecurity spurred by the disruption of mainstream national narratives. The point of silencing alternative narratives is to sharpen the distinction between self and other, us and them, loyalist and traitor, seen in accounts where the other is forcefully delegitimised alongside efforts to delegitimise in-group members who disseminate narratives of recognition about the other. ${ }^{53}$ Thus, the other, as well as those among the in-group who recognise the other as not being a threat, are often described as equally threatening to society. ${ }^{54}$ These measures are often taken for the sake of avoidance, a defence against feelings of ontological insecurity. ${ }^{55}$ In avoidance, states use mechanisms of selective exposure to information to exclude potentially disturbing knowledge. ${ }^{56}$ An active avoidance measure by the state would be to distance itself from the source that causes the identity threat, thus limiting the collective actor's exposure to actions that challenge it. ${ }^{57}$ This measure might be achieved by silencing pre-TJ activities and the actors that spread them.

\footnotetext{
${ }^{50}$ Yifat Gutman, Memory Activism: Reimagining the Past for the Future in Israel-Palestine (SAGE 2017) 98.

${ }^{51}$ Dmitry Chernobrov, 'Ontological Security and Public (Mis)Recognition of International Crises: Uncertainty, Political Imagining, and the Self' (2016) 37 Political Psychology 581, 582.

${ }^{52}$ Bahar Rumelili and Lisa Strömbom, 'Agonistic Recognition as a Remedy for Identity Backlash: Insights from Israel and Turkey' (2021) Third World Quarterly, https://doi.org/10.1080/01436597.2021.1951607.

${ }^{53}$ Lisa Strömbom, 'Identity Shifts and Conflict Transformation - Probing the Israeli History Debates' (2013) 18 Mediterranean Politics 78, 91.

${ }^{54}$ Browning and Joenniemi (n 46) 45.

${ }^{55}$ Lupovici (n 47) 818.

${ }^{56}$ Giddens (n 40) 188.

${ }^{57}$ Lupovici (n 47) 818.
} 
One such active avoidance measure, silencing sources that create ontological insecurity, is the implementation of memory laws. By using memory laws to strengthen the appearance of state stability, the narratives and voices of minority groups are excluded. ${ }^{58}$ This is done to strengthen the national memory in relation to the collective memory of such groups who have suffered from violence by the state. ${ }^{59}$ For example, the Russian memory law, first drafted in 2009, which forbade any criticism of Russia's actions during the Second World War, was designed to silence the argument of post-communist countries that the Soviet regime was oppressive rather than liberating. ${ }^{60}$

Paradoxically, according to the second dynamic, these attempts to silence pre-TJ instead can lead to an increase in public exposure to past injustices, as well as making hidden oppressive policies visible. ${ }^{61}$ This, therefore, could be seen as an unintended consequence of efforts to silence counter-narratives in pre-TJ processes, which serves to trigger public debate to convey previously silenced counter-narratives, implying a reversal of Lyotard's the différend. Memory laws tend to arise in specific contexts, triggered by specific events such as activities of TJ, which bring counter-narratives to public attention. ${ }^{62}$ Although these laws were created to block alternative narratives, they often amplify and make accessible the debate about past events. This was the case regarding the French memory law concerning France's history as a coloniser. The law was enacted in 2005 in response to an alternative narrative which focused upon the French role of exploitation and aggression during colonial times. ${ }^{63}$ Article 4 of this law stated that educational programmes must teach the 'positive role' of France's presence abroad. During and after the legislative process protests arose, and numerous French intellectuals and others signed a petition calling for the repeal of the controversial article. The protest resulted in the amendment of the law and the repeal of Article $4 .{ }^{64}$ The fact that a government chooses to respond to alternative narratives in a forceful way, such as trying to legislate against them, puts the controversial narratives at centre stage of public discourse. Therefore, even if the purpose of the legislation may be to silence and remove certain alternative narratives from the public discourse, in practice many people can become more knowledgeable about the unwanted narratives as it is brought to the centre of public attention. Even if the public may disagree with the alternative narratives and argue in favour of the authoritarian view, the argument in itself creates room in public discourse for previously unspoken issues.

\footnotetext{
${ }^{58}$ Gutman (n 50) 108.

59 ibid 101.

${ }^{60}$ ibid $107-8$.

61 ibid 98.

${ }^{62}$ ibid 108.

${ }^{63}$ Stiina Löytömäki, "The Law and Collective Memory of Colonialism: France and the Case of "Belated" Transitional Justice' (2013) 7 International Journal of Transitional Justice 205, 218-19.

${ }^{64}$ Raffi Wartanian, 'Memory Laws in France and their Implications: Institutionalizing Social Harmony,' Humanity in Action, November 2009, para 5, https://www.humanityinaction.org/knowledge_detail/memory-laws-in-franceand-their-implications-institutionalizing-social-harmony.
} 


\section{Pre-transitional Justice in Israel: Zochrot Activism}

We have conducted a case study of the NGO Zochrot (the female form of 'remembering' in Hebrew, which in itself refers to a break with the ordinary, masculine form of speaking), established in 2002. It was founded with the aim of raising awareness of the Palestinian Nakba (catastrophe) of 1947-48 among the broader Jewish Israeli public, to promote recognition of injustices carried out by the Israelis when Palestinians were expelled and deported from their lands in 1947-48, and to recognise Israel's moral obligation to grant the right of return of Palestinian refugees to their country of origin. ${ }^{65}$ Zochrot's views, since its inception, have been considered taboo by mainstream Israeli society as they contradict the Israeli official position, which denies any responsibility for the creation of the Palestinian refugee problem and has denied the right of return for Palestinian refugees. ${ }^{66}$ Initiatives by Zochrot, such as the Film Festival on Nakba and Return, disrupt the dominant Israeli identity narratives and have been described as existential threats by many leading politicians. ${ }^{67}$ Bringing up the narratives of the 1948 Palestinian refugees has ruptured the Jewish Israeli society's sense of being and its mainstream national identity of being a just and legitimate defender of one's own national cause throughout history. The idea of the Nakba unleashed high levels of ontological insecurity among some elements of the authorities, which over time created staunch backlashes.$^{68}$ To counter that perceived threat, strong actors worked hard to try to remove every trace of such discourses, such as the Nakba Nonsense campaign, which aimed to provide 'ammunition in the fight against the ignorance and lies which threaten to inundate us like a tsunami' ${ }^{69}$

Zochrot has thus aimed to recognise publicly Palestinian national narratives of past suffering and victimisation, which for many years had remained unspoken in the Israeli context of national remembering. Those narratives not only recognise Palestinian victimhood and legitimate rights, but also put blame on the Israeli Jewish collective, which is described as a perpetrator and guilty of unethical acts of expulsion during and after the war of 1947-48. The reactions of authorities as well as of right-wing groups were to launch forceful silencing campaigns against those actors as well as an attempt to initiate new laws which, to a large extent, prohibited the public voicing of Palestinian national narratives. Our empirical findings, however, point to a paradoxical line of

\footnotetext{
${ }^{65}$ Zochrot (n 2).

${ }^{66}$ Taba Non-Papers, Palestinian Position Paper on Palestinian Refugees and the Israeli Response, 21-22 January 2001, http://www.mideastweb.org/taba.htm.

${ }^{67}$ Nirit Anderman, 'Israel's Culture Minister Wants Tel Aviv Cinematheque Fined for Hosting Nakba Film Festival,' Haaretz, 16 November 2017, https://www.haaretz.com/israel-news/.premium-regev-wants-tel-aviv-cinematheque-fined-over-nakba-film-fest-1.5466036; Gili Izikovich, 'Israeli Cinematheque Should Lose Funding for Holding Nakba Film Fest, Says Minister', Haaretz, 25 November 2014, https://www.haaretz.com/cinemashould-lose-funding-for-nakba-films- 1.5335216

${ }^{68}$ Michal Ben-Josef Hirsch, 'Historical Acknowledgment as an Early Conflict Negotiation Strategy: A Feasibility Study of Israel/Palestine' (2021) 37 Negotiation Journal, 163, 181.

${ }^{69}$ Erez Tadmor and Arel Segal, Nakba Nonsense [Nakba Harta] (Im Tirtzu 2011) (in Hebrew), https://www.srugim.co.il/wp-content/uploads/2011/05/\%D7\%97\%D7\%95\%D7\%91\%D7\%A8\%D7\%AA-\%D7\%A0\%D7\%9B\% D7\%91\%D7\%94-\%D7\%97\%D7\%A8\%D7\%98\%D7\%90.pdf.
} 
events: the silencing and new legislation brought with it a simultaneous increase in public awareness of the Nakba (before then this was taboo in Israeli official discourse), which during and after the public debating of the law became well known to many, whether one chooses to sympathise with its truth claims or not.

Zochrot operates in several ways to recognise the Nakba. These include tours to displaced Palestinian towns and villages that existed in 1948, sign-posting Palestinian sites destroyed in the Nakba, videos with testimonials from the Nakba, a high school educational kit, memorial events, an annual Nakba film festival, an alternative truth and reconciliation commission, the creation of digital tools such as the iNakba app, among others. ${ }^{70}$

An example of a direct memorial action which aims to challenge the Israeli public sphere's denial of the Nakba has been described by Zochrot's founder, Eitan Bronstein: ${ }^{71}$

In 2007, the day Israel marked Independence Day, we organized a parade in Tel Aviv to mark the recognition of the right of return. We walked from the Bavli neighborhood, which was built on the Palestinian village Jamasin, to the centre of Tel Aviv, where the Palestinian village of Somayal stood. Every street we came to, we stopped to uncover its colonial past.

In 2014, on the eve of Israeli Independence Day, Zochrot launched the iNakba app, which, through a GPS tool in the mobile phone, allows users to locate and learn about hundreds of Palestinian localities destroyed during and as a result of the Nakba since $1948 .^{72}$ In 2012, at the Hebrew-Arab Theatre in Jaffa, Zochrot launched the book Once Upon a Land [Omrim Yeshna Eretz], which 'offers 18 tours in Palestinian neighborhoods and villages whose inhabitants were expelled by Israel during the Nakba and largely destroyed'. Liat Rosenberg, then director of Zochrot, said at the launch event that the book was an act of truth and reconciliation, because acknowledgement starts with awareness of what has been concealed and erased, not only from the physical space but from the personal space as well. ${ }^{73}$

Zochrot's activities, which began in 2002, were influenced by the fact that since the mid-1990s Palestinian citizens of Israel had started to raise the issue of Palestinian refugees on their political agenda. Umar al-Ghubari, member of the Executive Committee of Zochrot, argues that the year 1998, 50 years after the Nakba, was a turning point as it was sufficiently distant from 1948 to convey testimonies from the refugees and to organise an annual return march. ${ }^{74}$ The return march has been held every year since 1998 on the date on which Israel celebrates Independence Day; thousands of Palestinian citizens of Israel, together with Jews belonging to the left in Israel, march to one of the Palestinian displaced villages of 1948. 'J', a

\footnotetext{
${ }^{70}$ Zochrot, 'Pre-Transitional Justice', 2020, https://zochrot.org/en/wrapper/32.

${ }^{71}$ Eitan Bronstein, interview, 15 June 2020.

${ }^{72}$ Steven Klein, 'INakba: New Interactive App Documents Destroyed Palestinian Villages,' Haaretz, 5 May 2014, https://www.haaretz.com/new-interactive-app-documents-nakba-1.5247297.

${ }^{73}$ Observation, 7 September 2012.

${ }^{74}$ Umar al-Ghubari, interview, 25 June 2020.
} 
Palestinian citizen of Israel and student in a northern Israeli college who participated in the return march to the village of Al-Hadatha on 23 April 2015, said that the experience of the return march affected him so much he was able to feel how the villagers had suffered from the displacement. ${ }^{75}$

\section{The Nakba Law as a Consequence of Pre-transitional Justice ACTIVITIES}

During the Oslo peace process in the 1990s, Jewish Israelis were more open to alternative discourses and narratives, and a 'post-Zionist' narrative, which challenged the Zionist narrative of 1948, started to emerge. ${ }^{76}$ When the peace process collapsed in 2001 and the Al-Aqsa Intifada broke out, defenders of the Zionist narrative of 1948 acted to silence the post-Zionist narrative. ${ }^{77}$ For most Israelis the possibility of recognising the Palestinian right of return was seen then as equivalent to the destruction of the state. ${ }^{78}$ This illustrates how claims of recognition by some have been interpreted in terms of deeply felt existential fears by others. Although the period during which Israelis in general were exposed to critical discourse ended in 2001, information about the Nakba continued to be produced and disseminated by civil society actors. The purpose of the Nakba Law was to stop the production and spread of such information. ${ }^{79}$

Although the Nakba Law was enacted in 2011, discussions relating to it had already taken place in 2001, 2006 and 2009 in relation to earlier forms of the bill. According to the 2009 wording of the law, then called the Independence Day Law, the holding of any action or event to mark the establishment of the State of Israel as a day of mourning or of sorrow was prohibited. ${ }^{80}$ Violators would be liable to three years' imprisonment. Although the proposed law won the support of the Israeli government, public criticism against the criminal liability clause broke out. ${ }^{81}$ Following public protests, the 2011 amended version was presented, this time in the form of Amendment 40 to the Budget Foundations Law. It states: ${ }^{82}$

If the Minister of Finance sees that an entity has made an expenditure that, in essence, constitutes one of those specified below (in this section - an unsupported expenditure), he is entitled, with the authorization of the minister responsible for the budget item under which this entity is budgeted or supported, after hearing the entity, to reduce the sums earmarked to be transferred from the state budget to this

\footnotetext{
75 ' $\mathrm{J}$ ', interview, 15 June 2020.

${ }^{76}$ Uri Ram, Israeli Sociology: Text in Context, Sociology Transformed (Palgrave Macmillan 2018) 113-16, https:// doi.org/10.1007/978-3-319-59327-2.

${ }^{77}$ Ben-Josef Hirsch (n 68).

${ }^{78}$ Dan Zakay, Yechiel Klar and Keren Sharvit, 'Jewish Israelis on the "Right of Return”: Growing Awareness of the Issue's Importance' (2002) 9(2) Palestine - Israel Journal of Politics, Economics, and Culture 58, 62.

${ }^{79}$ Yifat Gutman and Noam Tirosh, 'Balancing Atrocities and Forced Forgetting: Memory Laws as a Means of Social Control in Israel' (2021) 46(3) Law \& Social Inquiry, 1, 5, https://doi.org/10.1017/lsi.2020.35.

${ }^{80}$ Roy Konfino and Mordechai Kremnitzer, 'Implications of the "Nakba Law" on Israeli Democracy', The Israel Democracy Institute, 22 June 2009, https://en.idi.org.il/articles/10132.

${ }^{81}$ The Association for Civil Rights in Israel, 'The Nakba Law', 11 September 2011, https://law.acri.org.il/en/knesset/nakba-law.

${ }^{82}$ Budget Basics Law, Amendment No 40, 2011 (emphasis added).
} 
entity under any law: (1) Rejecting the existence of the State of Israel as a Jewish and democratic state; (2) Incitement to racism, violence or terrorism; (3) Support for an armed struggle or act of terror by an enemy state or a terrorist organization against the State of Israel; (4) Commemorating Independence Day or the day of the establishment of the state as a day of mourning; (5) An act of vandalism or physical desecration that dishonors the state's flag or symbol.

As seen in the bill, the Ministry of Finance will impose financial penalties on any organisation or body that commemorates Israeli Independence Day as a day of mourning and withdraw their funding or support from the state. According to the initiator of the Nakba Law, former member of Knesset (MK) Alex Miller, the law is first and foremost a symbolic act in response to activities such as the return marches and memorial events for the Nakba that take place at universities every year around Independence Day: ${ }^{83}$

At that time in Israel, 2006 and beyond, all those demonstrations that were around the State of Israel's Independence Day ... buses with black flags, demonstrations of which some were very violent; there were also instances at Tel Aviv University to mark the Nakba Memorial; it was actually the trigger for the legislation, because for me it doesn't make sense that there is a situation in which the state's Independence Day is mentioned as a catastrophe ... it is contempt for the state emblem, so it makes sense and is reasonable to enact a law to prevent it.

Miller also pointed out that the sense of threat to the Israeli discourse from addressing the Nakba stems from the fact that the Israeli-Palestinian conflict is still ongoing. He argued that the problem with mentioning the Nakba is not that it is intended to be remembered but that it is intended as a form of incitement against the state. ${ }^{84}$

The public discussions and debates over the Nakba Law, which aims to exclude the Palestinian national narrative from the public sphere, ${ }^{85}$ are continuations of earlier controversies over the recognition or exclusion of the Palestinian narratives of the 1947-48 war. In 2007, the former Minister of Education, Yuli Tamir, approved the introduction of the Nakba curriculum to a geography book. This created much resistance and in 2009, following intense controversy over the issue, the then Minister of Education, Gideon Sa'ar, cancelled it. According to Yuli Tamir, the entry of the Nakba into the centre of the discourse alarmed the right and led to the counter-reaction. ${ }^{86}$

All of the interviewees we asked claimed to see a link between pre-TJ acts, such as those carried out by Zochrot, and the initiation and enactment of the Nakba Law. For example, according to journalist and former MK Daniel Ben-Simon, the law is an expression of the successful introduction of the narrative of the Nakba into the media and public discourse. He also argued that to some extent the law was an attempt to remain in control of regulating which historical narratives

\footnotetext{
${ }^{83}$ Alex Miller, interview, 7 April 2020.

${ }^{84}$ ibid.

${ }^{85}$ Michal Tamir, 'The Freedom to Exclude: The Case of Israeli Society' (2016) 49 Israel Law Review 237, 258.

${ }^{86}$ Yuli Tamir, interview, 16 June 2020.
} 
are disseminated publicly. ${ }^{87}$ Furthermore, the annual return march referred to above, together with pre-TJ activities such as alternative memorial ceremonies for the Nakba in universities, was mentioned by former MK Alex Miller as a major factor in the later enactment of the law by Israeli governing institutions. ${ }^{88}$

According to Zochrot's director at the time, Liat Rosenberg, the Nakba Law reflects the evocation of feelings of existential threat that the pre-TJ activities of remembering the Nakba caused among representatives of the Israeli establishment. ${ }^{89}$ This is explained by Umar al-Ghubari of Zochrot: ${ }^{90}$

When did Knesset members hear about the Nakba and about Nakba activities? I think they started reading it in Hebrew. They started meeting it in certain places, and it caused some Knesset members to take action to limit it, to fight it. When we held a conference on return at the Eretz Israel Museum in Tel Aviv, on the lands of al-Sheikh Muwannis' destroyed village, then Miri Regev and Eli Yishai wrote a letter of opposition... When Limor Livnat was the Minister of Education, and we published the Nakba map in Hebrew, she said: 'What is this false map, with points in it that say that there were Arab towns here? ... 'S So, all these challenges that Zochrot and other NGOs brought into the Israeli discourse in Hebrew have caused people who want to shut our mouths to take counter-action such as the Nakba Nonsense booklet.

Therefore, the trigger for the Nakba Law was when the issue of the Nakba exceeded the boundaries of Palestinian discourse to extend into the centre of Jewish-Israeli discourse.

\section{The Nakba Law: Curbing Freedom of Speech}

Once the Nakba discourse had filtered into the Israeli public sphere, many centre- and right-wing actors, politicians, NGOs and academics began the process of removing such discourses from public display. ${ }^{91}$ The climate for those who voiced and promoted alternative narratives of history such as Nakba became increasingly punitive, with the establishment demanding the prohibition of both materials and expressions of opinions that break with mainstream narratives of Zionism. ${ }^{92}$ The debate on the Nakba Law took place in such a climate of silencing.

Former MK Daniel Ben-Simon, during the deliberation of the Nakba Law in the Knesset, describes this climate as an atmosphere accompanied by a treasonous tone: 'If you accept the Nakba, you do not accept the establishment of the State of Israel ... the Nakba or the state, there is no middle ground'. ${ }^{93}$ In a similar vein, Chaim Levinson, political correspondent for Haaretz, illustrates in an interview that the purpose of the strong and forceful reactions was to

\footnotetext{
${ }^{87}$ Daniel Ben-Simon, interview, 28 June 2020.

${ }^{88}$ Alex Miller interview (n 83).

${ }^{89}$ Liat Rosenberg, interview, 11 June 2020.

${ }^{90}$ Umar al-Ghubari interview (n 74).

${ }^{91}$ Ben-Josef Hirsch (n 68).

${ }^{92}$ Or Kashti, ‘Are Teachers Introducing Nakba to Students against [the] State's Wishes?' Haaretz, 4 June 2009, https://www.haaretz.com/1.5060178.

${ }_{93}$ Daniel ben-Simon interview (n 87).
} 
sharpen the boundary between the self and the other. He argues that the Nakba Law was designed to mark those who oppose it as a fifth column. ${ }^{94}$ Marking all Palestinians and Israeli Jews who do not agree with the Nakba Law as a fifth column is part of a process of delegitimising actors who disagree with the hegemonic Zionist narrative. According to MK Ofer Cassif, the purpose of the Nakba Law is to humiliate and erase the identity of the Palestinian population in Israel. He argues that that intention of the Nakba Law and other similar laws is a process of reduction of the Palestinian minority and its views in all forms. ${ }^{95}$

Thus, any statement that acknowledges the Palestinian national collective identity is rendered seditious. The Nakba Law can thus affect the public by bringing to consciousness that it is unwise to engage in discussion about the Nakba and that anyone who acknowledges it will be publicly shamed and accused of treason. According to a former member of Zochrot, the greatest impact of the law is the internalisation of fear: ${ }^{96}$

When the first press publications began following the discussions around the law in its first draft, which would impose a prison sentence on anyone who mentioned or talked about the Nakba, it was very internalized, and teachers thought they should not engage in it. As a result, there has been a decrease in the number of requests from Zochrot to teach lessons about the Nakba [Zochrot developed an educational kit on the Nakba]. We made a lot of efforts to explain to teachers that this is not true, but at the same time there were a lot of attacks on teachers' freedom of expression, etc., and changes and all sorts of media messes .... So the debate on the law was silenced, and even if a smaller law comes out later, and legally teachers are not prevented from engaging in the Nakba, but something very big has been internalized and over the years even more ... The law was the first step and then there were other things that influenced the silence of the discourse.

These words suggest that the long-term effect of the Nakba Law may be the suppression of freedom of speech and instilling a sense of perpetual fear of expressing an alternative position on these issues. An example of the immediate impact of the discussion about the law in public discourse is an article published in the Haaretz newspaper ten days after the first draft of the law was approved by the Knesset Law and Justice Committee. According to the article, more than a hundred teachers then used the educational kit created by the Zochrot to study the Nakba. The title of the article suggests that it is a forbidden act: "Are Teachers Introducing Nakba to Students Against [the] State's Wishes?". ${ }^{97}$ Noa Jelinek, a teacher and a research student who in turn has interviewed dozens of teachers as part of a study on the Nakba discourse in classrooms, argues that the impact of the discussions about the first draft of the law created a chilling effect among teachers. She argues that the law has created a strong discourse of intimidation around it and that teachers now are reluctant to bring this discourse into the classroom. ${ }^{98}$

\footnotetext{
${ }^{94}$ Chaim Levinson, interview, 3 July 2020.

${ }^{95}$ Ofer Cassif, interview, 29 June 2020.

${ }^{96}$ Anonymous, former member of Zochrot, interview, 13 April 2020.

${ }^{97}$ Kashti (n 92)

${ }^{98}$ Noa Jelinek, interview, 16 June 2020.
} 
The impact of the law on diminishing freedom of speech relates also to cultural institutions, which are mostly funded by the state. Raneen Jeries, who founded and directed the Zochrot Nakba Film Festival, talked about the difficulties in finding venues for screening. ${ }^{99}$ Other members of Zochrot also said that blocking film screenings on the Nakba had been mostly successful in periphery areas outside Tel-Aviv and other urban centres. ${ }^{100}$ In other cases, various institutions used the Nakba Law as an attempt to prevent controversial events in their venues. In May 2019, for example, Tel Aviv University replied to a request to hold an event on campus to mark Nakba Day, stating that in the light of the Nakba Law 'it is not possible to approve the request in its current form'. However, after the Association for Civil Rights in Israel (ACRI) appealed against the rejection, Tel-Aviv University reversed its decision and approved a lecture on the subject of the Nakba. ${ }^{101}$

Discussions about the Nakba Law have thus had an impact on freedom of expression in Israel. In the short term this is a threat not only to the rights of the Palestinian minority in Israel but also to the freedom of expression of every person living in the country. ${ }^{102}$ If one recognises that the Nakba Law is part of a series of laws that suppress freedom of expression, then in the long term the effect may also be a violation of freedom of expression and self-censorship for fear of being perceived as a 'fifth column'.

If the long-term impact of laws such as the Nakba Law is the suppression of freedom of expression, self-censorship and the reduction of democratic public space, to what extent is pre-TJ responsible for this? It can be argued that pre-TJ actions were among the factors that led to the counter-reaction at state level by the enactment of the law. However, prior to the pre-TJ actions the public discourse did not challenge the hegemonic Zionist narrative, so it is possible that the oppression was even greater then because it was impossible to speak of the Palestinian experiences from 1947 to 1948.

\section{Debating the Nakba Law: Revoking the Differend}

The concept of the Nakba was something that could not be expressed in the main Israeli discourse until the last decade, and thus fits well with Lyotard's 'the différend'. ${ }^{103}$ Until recently the way to obscure the expulsion of the Palestinians was to say that it took place during a war, for security reasons, that they left on instructions from their own elite to do so, or that the Palestinian flight was a by-product of a war to defend Israel's right to exist. ${ }^{104}$ The change

\footnotetext{
${ }^{99}$ Raneen Jeries, interview, 28 June 2020.

${ }^{100}$ Natasha Dudinski, interview, 13 April 2020.

${ }^{101}$ Shira Kadari-Ovadia, 'Tel Aviv University Reverses Decision to Ban Nakba Lecture,' Haaretz, 19 May, 2019, https://www.haaretz.com/israel-news/.premium-tel-aviv-university-reverses-decision-to-ban-nakba-lecture-1. 7256872.

${ }^{102}$ Sami Michael, 'The Association's Response regarding the Bill Prohibiting the Mention of Nakba Events', 25 May 2009, https://law.acri.org.il/he/2150 (in Hebrew).

${ }^{103}$ Lyotard (n 48) 13.

${ }^{104}$ Avraham Sela and Alon Kadish, 'Israeli and Palestinian Memories and Historical Narratives of the 1948 War: An Overview' (2016) 21(1) Israel Studies 1, 7.
} 
is thus not only in making the word 'Nakba' familiar, but in the very recognition that it was and still remains a deep tragedy for the Palestinians, and the very possibility of speaking in non-military terms about what happened in 1948. According to Dr Tom Pessah, sociologist and member of the board of Zochrot: ${ }^{105}$

In interviews I did recently with fighters who fought in 1948, they used terms like Nakba. And it surprised me that people in this generation said so. I do not think that if I had interviewed them ten years earlier, I would have seen Palmach people use the term Nakba. And those who were interviewed by me are not marginal. They are not consumed with guilt over what they did. But they did use the term.

The Nakba Law led to the spread of the issue of the Nakba among many who were not aware of it before: 'Seven years ago I didn't know what the Nakba was; now it is in the newspaper, and not only the name, the newspaper writes what it is!'. ${ }^{106}$ In fact, in the years following the debate on the Nakba Law, the holding of Nakba Day memorial ceremonies have grown in and around Israeli university campuses. ${ }^{107}$

According to some of the interviewees in this study, the Nakba Law therefore has led to the opposite result of its purpose: the process of legislation has contributed to increasing awareness that the roots of the conflict do not lie in in the war of 1967 and its subsequent occupation of Palestinian territory, but in 1948 and the national predicament it created for the expelled Palestinian people who were deprived of their national home. ${ }^{108}$ Therefore, instead of not only repressing the Nakba and delegitimising proponents of the Nakba discourse, the debate on the law also led the Jewish Israeli public to be exposed not only to the Nakba concept, but also to the meaning it has for Palestinians. As argued by Umar al-Ghubari, member of Zochrot, the very discussion in the legislative process around the Nakba Law created a boomerang effect which has increased and expanded knowledge and awareness of the Nakba. ${ }^{109}$

Other Zochrot activists argued that each statement from the Knesset and the government about the Nakba is a great service for Zochrot as it brings the discourse back to the surface and motivates journalists to write about it. According to Raneen Jeries, member of Zochrot, one reason for the success of the Nakba Festivals was the opposition to its existence from ministers and Knesset members, which made the whole world aware of Zochrot: 'We wanted to send a bouquet of flowers to the Minister of Culture who, in her opposition, spread the word about the festivals'. ${ }^{110}$ Ami Asher, a Zochrot member, expressed the view that the former minister of culture, Limor Livnat, did a 'big favor' for Zochrot as her strong public reactions put the issue of the Nakba 'on the table'. ${ }^{111}$

\footnotetext{
105 Tom Pessah, interview, 28 June 2020.

${ }^{106}$ Gutman (n 50) 90.

${ }^{107}$ Gutman and Tirosh (n 79) 12.

${ }^{108}$ Kedar and Dudai (n 14) 374.

${ }^{109}$ Umar al-Ghubari interview (n 74).

${ }^{110}$ Raneen Jeries interview (n 99).

${ }^{111}$ Ami Asher, interview, 12 March 2020.
} 
The view that the Nakba Law paradoxically served to increase awareness and recognition of the events of the Nakba has not only been found among pre-TJ activists from Zochrot, but also among politicians, journalists and other public figures. Ronit Tirosh, former MK and former director general of the ministry of education, said that ' $[\mathrm{t}]$ he law put this concept [Nakba] on the agenda ... a lot of people did not understand, did not know or did not see it before'. ${ }^{112}$ Yuli Tamir, former minister of education, also claimed that out of the debate over the Nakba Law the issue of the Nakba came up for discussion and gained prominence. ${ }^{113}$ Similarly, journalist Noam Sheizaf argued that the Nakba Law had a 'strange effect'. ${ }^{114}$ Although its purpose was to silence the debate on Israeli responsibility for the expulsion of the Palestinians of 1948, the term 'Nakba' itself has become part of the mainstream discourse. ${ }^{115}$

Moreover, according to journalist Rino Zror, what happened with the Nakba Law is similar to what happened with the law of raising the electoral threshold (in 2014), in the sense that the objective was to harm the Arab population in Israel; the result was a more respectable representation of this group numerically in the Knesset and in raising awareness of Palestinian experiences. ${ }^{116}$ According to Odeh Bisharat, an op-ed columnist for Haaretz and Al-Atikhad newspapers: ${ }^{117}$

[T]here is also something good in this commotion [after the legislation of the Nakba Law]. At least, there's no denial of the Nakba. Nobody claims the whole thing is fairy-tale. The Palestinian narrative has won. The narrative that in ' 48 a people was exiled, by force, from its land, has seared into Israeli and global consciousness.

It seems in the short term that the discussions and the long legislative process of the Nakba Law have increased the familiarity of the Jewish-Israeli public not only with the term 'Nakba' but also with its meanings for the Palestinian people. From the above interviews, both with Zochrot activists and with others, recognition by the Jewish-Israeli public of the Palestinian narrative about the 1947-48 war has increased. Nevertheless, this does not imply that the Jewish-Israeli public has become more supportive of this narrative. However, what was previously non-existent in Israeli mainstream discourse has now become more familiar through widespread public debate.

\section{Conclusions}

In this study we ventured into the reactions to and the effects of pre-TJ activities. We departed from the paradox that while some actors might respond to undesired pre-TJ activities with

\footnotetext{
${ }^{112}$ Ronit Tirosh, interview, 21 June 2020.

${ }^{113}$ Yuli Tamir interview (n 86).

${ }^{114}$ Noam Sheizaf, 'Despite Efforts to Erase It, the Nakba's Memory Is More Present than Ever in Israel,' +972 Magazine (blog), 14 May 2013, https://www.972mag.com/despite-efforts-to-erase-it-the-nakbas-memory-ismore-present-than-ever-in-israel.

115 ibid.

${ }^{116}$ Rino Zror, interview, 8 July 2020.

${ }^{117}$ Odeh Bisharat, 'The Palestinian Narrative Has Won,' Haaretz, 24 March 2011, https://www.haaretz.com/thepalestinian-narrative-has-won-1.5141267.
} 
attempts to inhibit freedom of speech through legislation and delegitimising campaigns, that very activity may in itself increase public awareness of past injustices, as well as making hidden oppressive policies visible, thus widening recognition of different understandings of the past to the general public. A case study of reactions to pre-TJ in Israeli society was conducted, which deepened understandings of the relationship between these partly disparate responses. We established that many Israeli actors indeed conceived pre-TJ measures to be a threat to the ontological security of the Israeli state and its Jewish people. The conclusion of the study is that the so-called Nakba Law, which was enacted in 2011 as a response to threatening pre-TJ actions by Zochrot and other NGOs promoting similar narratives, can be seen as simultaneously silencing and raising awareness of alternative narratives of history. Thus, attempts to reinstate the silencing instead served to further increase awareness of what before was unspeakable. The Nakba Law is part of a set of laws that attempted to define who is perceived as a traitor and who is loyal, resulting in inhibited freedom of speech and thus weakened democratic values; on the other hand it was also a trigger for a wider increase in awareness of the Nakba in Israeli public discourse and among the general population.

It seems that in the short term, during the years of public discussions about the Nakba Law, the issue became very prominent in Israeli public debate, and hence recognition of the concept of the Nakba and its meaning increased, whether one was in opposition to or in support of it. In the medium term, spanning several years, it can be seen that in the years following its enactment, the Nakba Law was one of a series of new laws which aimed to strengthen Israeli Jewish national awareness such as the Nation-State Law (2018), which enshrines Israel as the national home of the Jewish people. ${ }^{118}$ The Nakba Law and the Nation-State Law are examples of laws which mark a stark difference between self and other and friend and enemy. By so doing, they clearly play a part in the erosion of democratic values such as freedom of speech and equity of all citizens. According to a longer-term perspective when the issue of the Nakba no longer makes it to the headlines, it is difficult to judge whether the debates about the Nakba Law, its implementation and implications will have an impact on the familiarity with the Palestinian narrative for average Israeli Jews. Thus, even though memory laws such as the Nakba Law might expand the public space with knowledge of previous taboos, that expansion might very well implode a few years down the road, when the eye of the media and public opinion has turned elsewhere.

An important lesson from this study is that pre-TJ, even in entrenched conflicts-in-resolution, may invoke discursive dynamics which reach the general public through debate in the media and the political and judicial spheres. Thereby previous taboos in the conflict - such as normative dimensions regarding the conflict's alleged victims and perpetrators - can then be vented and reach public consciousness, even though the general climate of the peace process might be more closed and restrictive to new narratives than ever. We have shed light on such processes in the Israeli-Palestinian conflict, but the theoretical proposition regarding attempts to impose a silencing by enacting new memory laws, which then bring the taboo topic back into consciousness raised by

\footnotetext{
${ }^{118}$ Knesset News, Full text of Basic Law: Israel as the Nation State of the Jewish People, 19 July 2018, https:// main.knesset.gov.i1/en/News/PressReleases/Pages/Pr13978_pg.aspx.
} 
renewed debate, is highly relevant also for other conflicts-in-resolution. We hope, therefore, that our initial thoughts and investigations in relation to conflict narratives, ontological insecurity and elaborations on how what has been 'the différend' before pre-TJ processes can be spurred, will inspire researchers with interest in $\mathrm{TJ}$ in protracted conflicts to continue theoretical as well as empirical investigations to highlight the potentials as well as the pitfalls of such processes. 